Tropical Journal of Pharmaceutical Research January 2017; 16 (1): 211-218

ISSN: 1596-5996 (print); 1596-9827 (electronic)

(c) Pharmacotherapy Group, Faculty of Pharmacy, University of Benin, Benin City, 300001 Nigeria.

All rights reserved.

Available online at http://www.tjpr.org

Original Research Article

http://dx.doi.org/10.4314/tjpr.v16i1.28

\title{
Diagnostic utility of leptin and insulin-like growth factor binding protein-2 in hepatocellular carcinoma of diabetic and non-diabetic Egyptian patients
}

\author{
Mekky M Abouzied ${ }^{1,2 \star}$, Maiiada H Nazmy ${ }^{2}$, Randa M Mohamed ${ }^{2}$, Michael A \\ Fawzy $^{2}$, Heba M Eltahir ${ }^{1}$ \\ ${ }^{1}$ Departments of Pharmacology and Toxicology, College of Pharmacy, Taibah University, Medina, Kingdom of Saudi Arabia \\ ${ }^{2}$ Department of Biochemistry, Faculty of Pharmacy, Minia University, Minia 61511, Egypt \\ *For correspondence: Email: m_meky2001@yahoo.com
}

Received: 30 June 2016

Revised accepted: 3 December 2016

\begin{abstract}
Purpose: To elucidate the possible diagnostic utility of adipokines and insulin growth factor binding proteins in hepatocellular carcinoma (HCC) diabetic subjects.

Methods: Seventy five patients were divided equally into 3 groups as follows: healthy normal control (NC), non-diabetic hepatocellular carcinoma (HCC) and diabetic hepatocellular carcinoma (HCC-DM). Serum levels of leptin, insulin growth factor binding protein-2 (IGFBP-2) and alpha fetoprotein (AFP) were measured. Correlation and receiver operating characteristics (ROC) analysis was carried out.

Results: HCC and HCC-DM groups showed changes in body mass index (BMI, $p>0.05$ and $p<0.001$ respectively), glucose, insulin, homeostatic model assessment-insulin resistance (HOMA-IR), liver function tests and AFP $(p<0.001)$. Leptin levels increased significantly in both HCC and HCC-DM $(p<$ $0.001)$. Furthermore, IGFBP-2 showed significant increase in both groups $(p<0.001)$. Both leptin and insulin-like growth factor binding protein-2 (IGFBP-2) displayed significant positive correlation with AFP $(p<0.001)$. ROC analysis indicate different diagnostic accuracies for the tested markers for the various groups.

Conclusion: Leptin and IGFBP-2 demonstrate significant potentials as diagnostic tools for HCC patients, especially diabetic cases, with IGFBP-2 displaying the highest diagnostic accuracy for HCC and HCC-DM groups.
\end{abstract}

Keywords: Hepatocellular carcinoma, Diabetes mellitus, Leptin, Insulin-like growth factor-binding proteins-2, Adipokines

Tropical Journal of Pharmaceutical Research is indexed by Science Citation Index (SciSearch), Scopus, International Pharmaceutical Abstract, Chemical Abstracts, Embase, Index Copernicus, EBSCO, African Index Medicus, JournalSeek, Journal Citation Reports/Science Edition, Directory of Open Access Journals (DOAJ), African Journal Online, Bioline International, Open-J-Gate and Pharmacy Abstracts

\section{INTRODUCTION}

Obesity and type 2 diabetes mellitus may have a positive association with both the risk of cancer and cancer-related mortality. Given the dramatic increase in rates of obesity and diabetes [1], this connection is a great public health concern. The exact molecular mechanisms for this association are yet unknown, but chronic, sustained hyperinsulinaemia in these insulin-resistant syndromes appears to play a role in the neoplastic transformation process [2]. A more detailed molecular and mechanistic understanding is required to interpret existing data. Understanding these mechanisms may lead to novel diagnostic and prognostic strategies for HCC [3].

For many years adipose tissue was believed to act primarily as an insulator and energy store for 
the body, facilitating the storage of lipids to better enable survival during periods of fasting. It is now well established that adipose tissue is additionally a labile secretory organ, with a unique secretome of biologically active molecules. Adipokines are multifunctional protein molecules that are involved in several processes like metabolism, inflammation, angiogenesis, and proliferation [4]. Adiponectin and leptin are the most abundant adipocytokines produced by adipocytes, and the best-studied molecules in this class so far [5].

Leptin is a $16 \mathrm{kDa}$ bioactive protein encoded by the $\mathrm{Ob}$ gene, secreted from adipocytes as well as other tissues, which acts as a regulator of energy to control satiety through stimulation in the central nervous system as well as to modulate glucose and insulin homeostasis through activation in peripheral tissues [6].

The insulin-like growth factor (IGF) system has a highly conserved function in mammals and plays a critical role in energy metabolism and cell renewal in response to nutrients. IGF pathway is not only involved in cell growth in tissue culture, but it is also involved in cellular proliferation, migration and malignant transformation. It comprises IGF-I and IGF-II, type I and type II receptors, and a family of IGF binding proteins (IGFBPs) that specifically bind IGFs. The IGF pathway revolves around 4 essential components [7]. The first component contains the IGF ligands, which include both IGF-1 and IGF-2. They are slightly different from insulin structurally by containing an additional domain, which could account for their dramatically different role in neoplasms in comparison to insulin [8].

The IGF ligands bind to the second component of the IGF axis, the receptors which include IGF1 receptor (IGF-1R) and IGF-2 receptor (IGF-2R) [7]. The third component of the IGF axis refers to the insulin receptor substrate (IRS) and Shc proteins, which are the major signals downstream of IGF-1R activation [9]

The last key component of the IGF axis consists of IGF binding proteins (IGFBPs). There are 6 members of IGFBPs with high affinities for IGF-1 and IGF-2. For instance, IGFBPs 1-4 bind both IGF-1 and IGF-2 with similar affinities, yet IGFBP-5 and 6 strongly prefer IGF- 2 as their ligand [10]. In contrast to IGFBP-3, other IGFBPs such as IGFBP-2 seem to increase the bioavailability of IGF ligands [7]. In the current study, we aim to further explore the complex relation between obesity, diabetes and HCC in addition to comparing the secretion patterns of leptin and IGFBP-2 in HCC diabetic and nondiabetic patients compared to corresponding healthy controls.

\section{METHODS}

Seventy five patients were recruited from Minia National Cancer Institute, Minia, Egypt over a one-year period after securing ethical their approval. The study protocol was approved by the Ethics Committee of the Faculty of pharmacy, Minia University, Egypt (approval no. 2014-31) and is in accordance with the guidelines of Helsinki Declaration [11]

\section{Inclusion criteria}

Only patients with recently-diagnosed, histologically-proven HCC, and who had not yet received treatment were included in this study. Patients diagnosis was based on radiological imaging, laboratory tests and clinical investigation according to the protocol of Minia National Cancer Institute. Individual patient profiles were collected from medical records to determine their clinical stages. Also diabetic patients recently-diagnosed with biochemicallyproven HCC who had not yet received treatment (i.e. insulin, insulin-releasing or adiponectininducing drugs) were included. Diabetes mellitus was confirmed by fasting glucose levels over $126 \mathrm{mg} / \mathrm{dl}$ or two hour post-prandial glucose levels over $200 \mathrm{mg} / \mathrm{dl}$.

\section{Exclusion criteria}

Patients who were positive for hepatitis $B$ surface antigen (HBsAg) and/or anti-HCV antibody were excluded from this study.

\section{Study groups}

Group I: 25 normal age- and sex-matched healthy adult patients served as normal control group.

Group II: 25 non-diabetic, histologically-proven HCC patients.

Group III: 25 diabetic, histologically-proven HCC patients.

Blood samples were collected using venipuncture technique in glass test tubes and were left to clot for a period of $30 \mathrm{~min}$ at $37^{\circ} \mathrm{C}$. Samples were then centrifuged at 3,000 rpm for $10 \mathrm{~min}$. The supernatants (sera) were collected and stored at $-80^{\circ} \mathrm{C}$. 
Sample collection and serum glucose/insulin test). $P<0.05$ were considered as significant. levels

Correlation and ROC analysis was done using Graph Pad Prism (version 5.00 for windows,

Venous blood (5 mL) was withdrawn from the GraphPad software, San Diego, California, USA) subjects following $12 \mathrm{~h}$ overnight fast. Serum statistical software.

glucose level was measured using Stanbio kit (Stanbio laboratory, USA). Insulin levels were determined using ELISA Biosource kits according to the manufacturer's instructions.

\section{RESULTS}

General characteristics and liver function tests of patients are shown in Table 1. HCC group

\section{Homeostasis model assessment of insulin resistance}

The index of insulin resistance estimated by the homeostasis model assessment (HOMA) was calculated using relationships between blood glucose $(\mathrm{Bg}, \mathrm{mmol} / \mathrm{L})$ and insulin $(\mathrm{l}, \mathrm{mUl} / \mathrm{L})$ levels according to Eq 1 [12].

$\mathrm{HOMA}-\mathrm{IR}=(\mathrm{I} \times \mathrm{Bg}) / 22.4$

\section{Biochemical analysis}

Serum activities of liver enzymes alanine aminotransferase (ALT) and aspartate aminotransferase (AST) and serum levels of total and direct bilirubin (TB and DB) were measured using Randox ${ }^{\circledR}$ kits (Randox laboratories Ltd, USA).

\section{Enzyme-linked immunosorbent (ELISA)}

assay

Serum levels of alpha-fetoprotein, leptin (Diagnostics Biochem Canada Inc), adiponectin, insulin growth factor binding proteins-2 and -3 were measured using RayBio-Human ELISA kits, following the instructions of the manufacturer.

\section{Statistical analysis}

Data are expressed as mean \pm standard deviation (SD) of 25 patients in each group, using one-way analysis of variance (ANOVA showed a non-significant increase in $\operatorname{BMI}(p>$ 0.05 ), while a significant decrease in fasting glucose levels (hypoglycaemia) was observed in this group $(p<0.001)$. In addition, HCC group showed significant increase in age, HOMA-IR and serum levels of fasting insulin, ALT, AST, total- and direct bilirubin (TB and DB respectively) when compared to normal control $(p<0.001)$. On the other hand, significant increase in BMI $(p<0.01)$, age, fasting glucose and insulin, ALT, AST, TB and DB $(p<0.001)$ was observed in HCC-DM group when compared to normal control (Table 1).

AFP levels were highest in HCC-DM group and lowest in normal control. Its increase in both HCC and HCC-DM groups was statistically significant when compared to normal control $(p<$ 0.001) (Figure $1 \mathrm{~A}$ ). Both HCC and HCC-DM groups showed significant increase in serum levels of leptin when compared to normal control $(p<0.001)$ (Figure 1B).

Serum IGFBP-2 level was highest in HCC-DM group and lowest in normal control group. Its level was significantly increased in both HCC and HCC-DM groups when compared to normal control $(p<0.001)$ (Figure 1C). Pearson's correlation coefficient test between serum level of leptin or IGF-BP-2 versus AFP showed significant $(p<0.001)$ positive correlation between either serum leptin or IGFBP-2 levels and AFP ( $r=0.9551$ for leptin, and $r=0.95$ for IGF-BP-2 respectively, Table 2 and Figure 2).

Table 1: General characteristics and liver function tests

\begin{tabular}{|c|c|c|c|}
\hline Variable & NC & $\mathrm{HCC}$ & HCC-DM \\
\hline Age & $29.15 \pm 8.57$ & $57.72 \pm 4.75^{\star \star \star}$ & $59.82 \pm 6.01^{\star \star \star}$ \\
\hline Gender (M/F) & $23 / 2$ & $18 / 7$ & $16 / 9$ \\
\hline BMI & $22.19 \pm 3.03$ & $21.72 \pm 3.29^{\mathrm{ns}}$ & $26.16 \pm 3.51^{* *}$ \\
\hline Fasting glucose (mmol/L) & $5.55 \pm 0.45$ & $4.23 \pm 0.27^{\star \star \star}$ & $8.6 \pm 16.91^{* \star *}$ \\
\hline Fasting Insulin $(\mu \mathrm{IU} / \mathrm{ml})$ & $2.33 \pm 0.23$ & $6.16 \pm 0.77^{\star \star *}$ & $6.97 \pm 0.72^{\star \star *}$ \\
\hline HOMA-IR & $0.58 \pm 0.01$ & $1.16 \pm 0.02^{\star \star *}$ & $2.67 \pm 0.04^{\star * *}$ \\
\hline ALT (U/L) & $29.33 \pm 3.29$ & $61.33 \pm 5.05^{\star * *}$ & $103.71 \pm 11.09^{* * *}$ \\
\hline AST (U/mL) & $29.52 \pm 6.13$ & $69.82 \pm 11.61^{* * *}$ & $88.32 \pm 13.7^{\star \star \star}$ \\
\hline Total Bilirubin (mg/dl) & $0.76 \pm 0.11$ & $1.59 \pm 0.55^{\star \star \star}$ & $1.46 \pm 0.59^{\star * \star}$ \\
\hline Direct Bilirubin (mg/dl) & $0.11 \pm 0.06$ & $0.59 \pm 0.09^{* * *}$ & $0.32 \pm 0.09^{* * *}$ \\
\hline
\end{tabular}

$\mathrm{NC}=$ normal control, $\mathrm{DM}=$ Diabetes mellitus, $\mathrm{HCC}=\mathrm{Hepatocellular}$ carcinoma. $\mathrm{BMI}=$ body weight $(\mathrm{kg}) /$ the square value of height $\left(\mathrm{m}^{2}\right)$. HOMA-IR $=$ Insulin $(\mu \mathrm{lU} / \mathrm{ml}) \times$ glucose $(\mathrm{mmol} / \mathrm{L}) / 22.4$ 

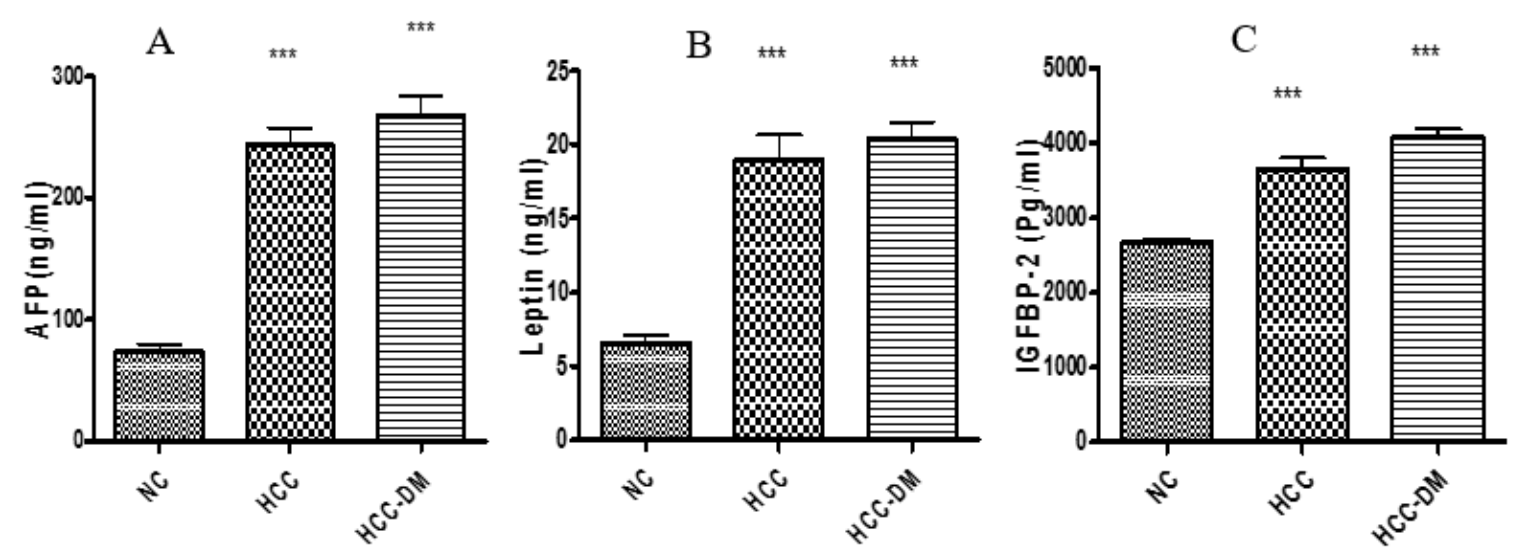

Figure 1: Serum concentrations of AFP (A), Leptin (B), IGFBP-2 (C) in various groups, compared to normal control. Data were expressed as mean \pm SD. Significant difference between groups are analysed by unpaired tstudent test, where: ${ }^{* * *} p<0.001$ : highly significant, ${ }^{* *} p<0.01$ : significant, ${ }^{*} p<0.05$ : mildly significant, $p>$ 0.05: non-significant, $\mathrm{NC}=$ normal control, $\mathrm{DM}=$ Diabetes mellitus, $\mathrm{HCC}=$ hepatocellular carcinoma

Table 2: Pearson correlation coefficient test between serum levels of leptin, IGF-BP-2 versus AFP.

\begin{tabular}{lcc}
\hline Variable & AFP vs Leptin & AFP vs IGFBP-2 \\
\hline Pearson $r$ & 0.9551 & 0.9500 \\
95\% confidence interval & 0.9247 to 0.9734 & 0.9163 to 0.9704 \\
R squared & 0.9123 & 0.9025 \\
$\mathrm{P}$ (two-tailed) & $p<0.0001$ & $p<0.0001$ \\
\hline
\end{tabular}

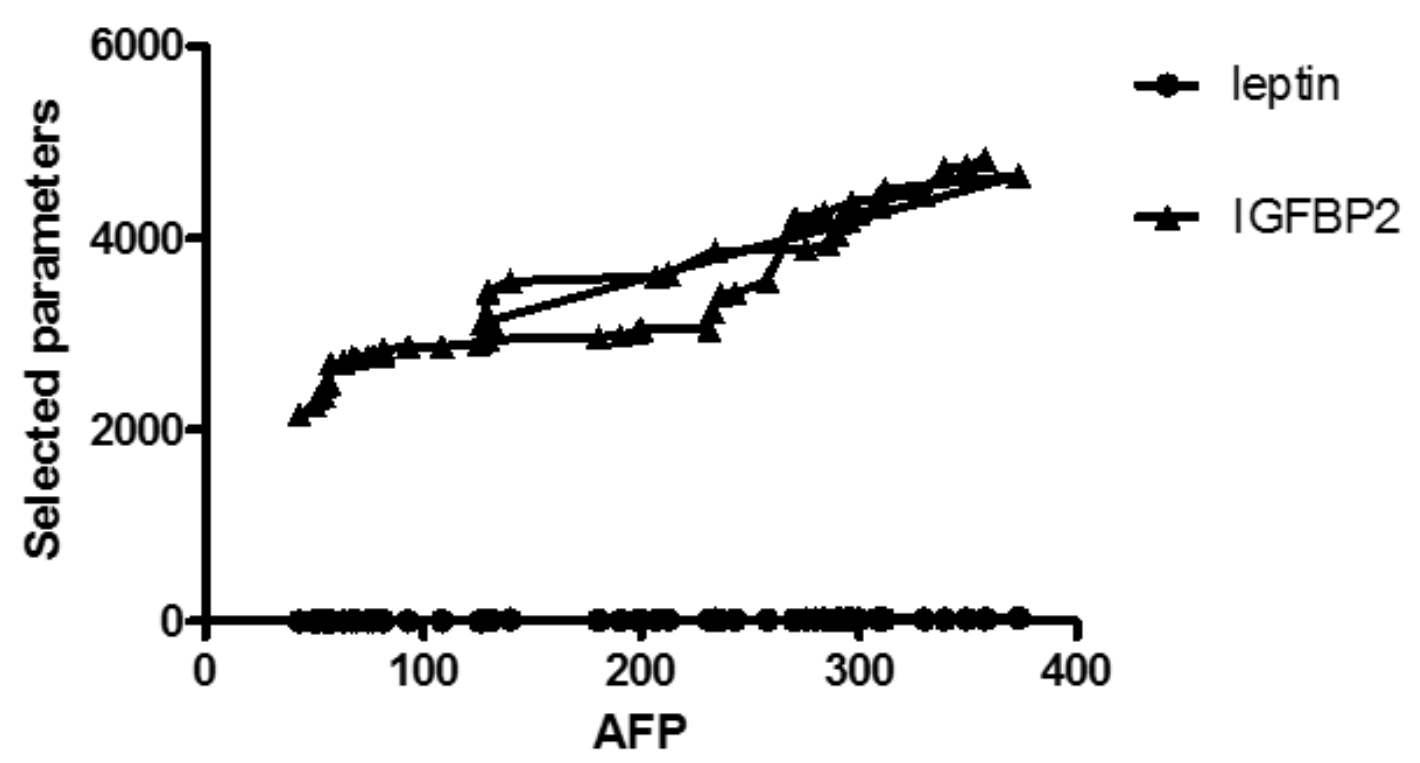

Figure 2: Pearson's correlation coefficient test for serum levels of leptin, IGF-BP-2 versus AFP

Table 3: Area under the curve (AUC), cut-off values, sensitivity and specificity for different markers

\begin{tabular}{lccccc}
\hline Marker & AUC & Cut-off & Sensitivity (\%) & Specificity & Diagnostic \\
\hline HCC vs NC & & & & & \\
AFP $(\mathrm{ng} / \mathrm{ml})$ & 0.994 & $>126$ & 100 & 94 & 97 \\
Leptin $(\mathrm{ng} / \mathrm{ml})$ & 0.9640 & $>12.7$ & 84 & 94 & 89 \\
IGFBP-2 & 0.9806 & $>2919$ & 100 & 94.7 & 97.4 \\
HCC-DM vs NC & & & & & \\
AFP $(\mathrm{ng} / \mathrm{ml})$ & 0.9945 & $>126.6$ & 100 & 94.7 & 97.4 \\
Leptin $(\mathrm{ng} / \mathrm{ml})$ & 0.9640 & $>13.6$ & 89 & 94 & 91.5 \\
IGFBP-2 & 0.9806 & $>3010$ & 100 & 94.9 & 97.5 \\
\hline
\end{tabular}

Note: Overall diagnostic accuracy is the weighted average of a test's sensitivity and specificity 
(A)-ROC of AFp

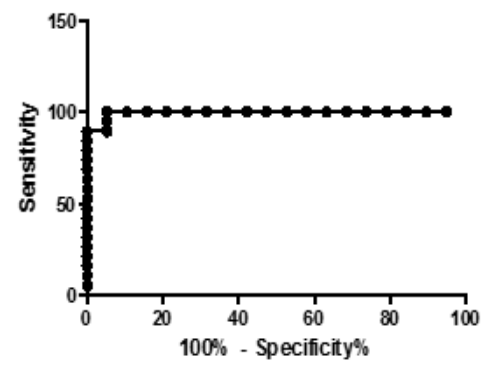

(A)-ROC of Leptin

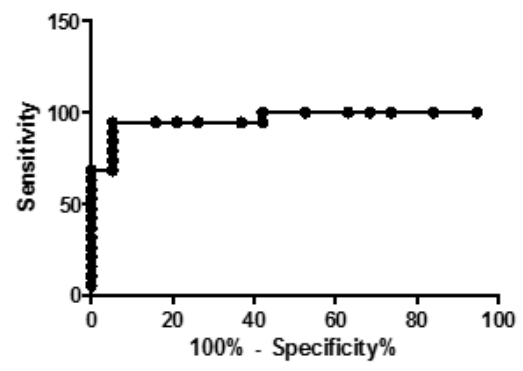

(A)- ROC of IGFBP-2

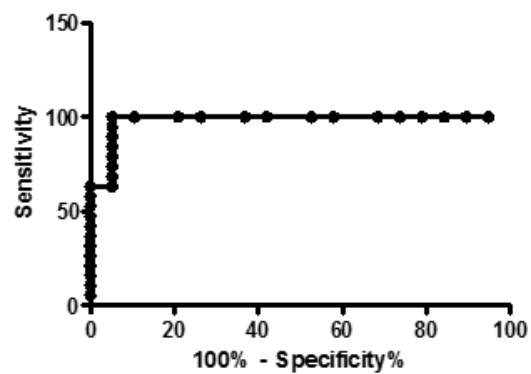

(B)- ROC of AFp

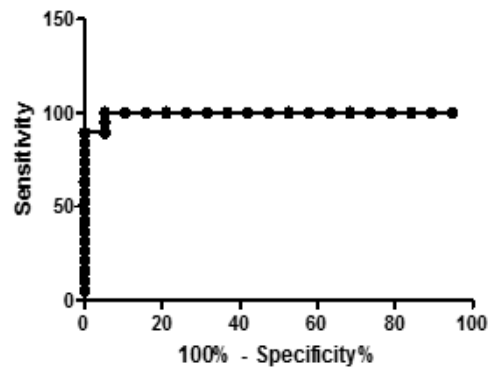

(B)- ROC of Leptin

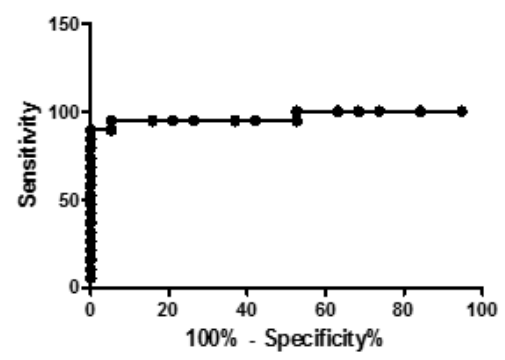

(B)- ROC of IGFBP-2

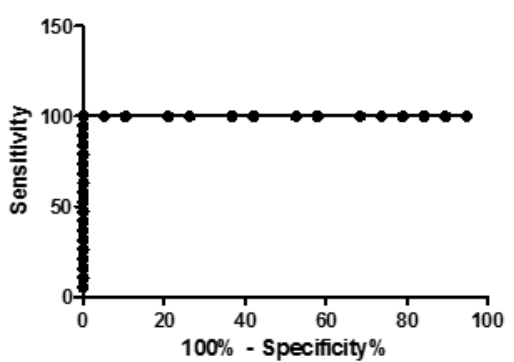

Figure 3: Receiver Operating Characteristic (ROC) curve for AFP, Leptin, IGFBP-2 in various situations. A: HCC vs. normal control, B: HCC-DM vs normal control

ROC analysis including area under the curve found that diabetic women and men had an (AUC), cut-off values, sensitivities, specificities and increased risk of $1.40(95 \% \mathrm{Cl}: 1.05-1.86)$ and diagnostic accuracies for different markers were 2.26 (95\% \% : $1.89-2.70)$ for developing HCC, done, and the overall diagnostic accuracy was respectively. But even if the role of impaired calculated as the weighted average of a test's glucose metabolism is important in sensitivity and specificity. Arranging the different hepatocarcinogenesis, its impact on HCC natural groups according to their diagnostic accuracy history is still controversial. Recently, Howell et al resulted in the following ranking: IGFBP-2 > AFP > [15] compared diabetic and-non diabetic subjects Leptin (Table 3 and Figure 3).

\section{DISCUSSION}

An increased incidence of HCC in obese and diabetic subjects has led to the necessity to characterize the role of metabolic syndrome in liver carcinogenesis. Metabolic syndrome includes multiple disorders including glucose intolerance, hyperglycemia, Type 2 diabetes mellitus, overweight, high blood pressure and dyslipidemia [13]. In 2012, Campbell et al [14] conducted a large prospective cohort study which included over one million subjects and treated for HCC and couldn't find a survival difference between both groups. In contrast, a meta-analysis by Wang et al [16] found that patients with co-existing type II DM had a shorter survival time and a higher risk for tumor recurrence after curative treatments. This study highlighted the important role of adipokines and IGFBPs in mediating the interrelation between obesity, type II DM and HCC, and demonstrated different secretion patterns and diagnostic utilities for these parameters in various situations (i.e. diabetic HCC and non-diabetic HCC patients). 
Diabetic patients showed significant biochemical variations in BMI, glucose homeostasis, insulin resistance and liver function tests. These finding are consistent with former observations which explained in details the role of liver in glucose homeostasis and the interaction between type II DM and liver disease [17].

The pathophysiological hallmarks of type 2 diabetes mellitus are insulin resistance and $\beta$-cell dysfunction. There is now consensus that a variety of adipokines can modify both insulin sensitivity and secretion. Therefore they offer candidate mechanisms for a link between obesity and type 2 diabetes [18].

It has been suggested that the association between plasma leptin and diabetes may be a manifestation of an underlying leptin resistance mediated by obesity [19]. Some studies have reported that there is no association between plasma leptin levels and diabetes [20], whereas a significant positive correlation between both conditions was reported by other groups [21]. However, other studies reported an inverse relation [22]. Also, few studies reported that the association between plasma leptin and DM was observed only in men and not in women [21]. Consistent with the low circulating levels of adiponectin observed in type II DM, adiponectin concentration was found to be inversely related to leptin, insulin resistance and central adiposity [23].

Increasing evidence suggests that the insulin-like growth factor (IGF) axis may play a role in glucose homeostasis [24]. IGF-I shares structural homology and downstream signalling pathways with insulin, and like insulin, IGF-I can promote glucose and fatty acid uptake in peripheral tissues [25]. In the current study, IGFBP-2 levels were significantly increased in both $\mathrm{HCC}$ and HCC diabetic patients. Consistent with this finding, cross-sectional studies have found that individuals with impaired glucose tolerance or diabetes have possibly higher IGFBP-3 levels than healthy individuals [26]. A positive association between high IGFBP-3 and diabetes can be explained by its sequestration of IGF-I [27]. In addition to this effect, some IGFBPs like IGFBP-2 may also have important IGFindependent, potentially beneficial effects on glucose uptake [28]. IGFBP-2 circulates at equimolar or lower molar concentrations compared to IGF-1, unlike hormone inhibitors which usually circulate in molar excess compared to the ligand. In vivo, IGFBP-2 has been shown to play a role to modulate IGF signalling in diabetes. The precise function of IGFBP-2 is poorly understood, and it is not well established whether it inhibits or activates IGF-1 signalling in vivo or if it has actions independent of IGF [29].

Altered levels of adipokines or their cognate receptors in cancers can ultimately lead to an imbalance in downstream molecular pathways [30]. Leptin has been shown to increase proliferation, migration, and invasion of cancer cells [31] as well as contribute to release of VEGF [32]. The molecular mechanisms through which leptin affects cancer cell behaviour still require further elucidation. It is believed that cross-talk between adipokines as well as the activation of multiple pathways via activation of Janus-activated kinase (JAK2) and subsequent up regulation of Ras and PPAR-y keep proliferative signalling in balance [33]. In our study we also aimed to elucidate the secretion patterns of adipokines and IGF axis and to compare these patterns in HCC diabetic and non-diabetic HCC patients.

Leptin was significantly increased in HCC and diabetic HCC patients. This may be, in part, related to non-significant change in $\mathrm{BMl}$ in nondiabetic $\mathrm{HCC}$ as well. A number of studies have attempted to elucidate the possible effects of leptin in HCC development. In patients with hepatocellular carcinoma, elevated leptin levels have been reported in comparison to normal or preoperative levels [34].

Insulin-like growth factor binding proteins (IGFBPs) constitute a family of six circulating proteins that bind insulin-like growth factor (IGF)I and -II with high affinity [35]. In our study, serum levels of IGFBP- 2 showed significant increase in both diabetic and non-diabetic HCC patients. These data are in accordance with previous reports indicating that serum levels of IGFBP-2 were significantly higher while IGFBP-3 levels were normal [36] or significantly lower [37] in patients with HCC compared to healthy subjects.

IGFBP-2 has been considered as an inhibitory factor for IGFs, particularly of IGF-II [35]. IGFBP-2 expression changes dynamically showing its highest levels during the prenatal stages. After birth, the expression of IGFBP-2 decreases significantly, however, IGFBP-2 is the second most abundant IGFBP in serum. It is also altered in various pathological conditions including HCC [38]. IGFBP-2 is not only a modulator of IGF/IGF receptor signalling, but also a pleiotropic factor which has important effects on cellular proliferation, motility, interactions with the extracellular matrix and transcription [29]. 


\section{CONCLUSION}

Based on the obtained data, leptin and IGFBP-2 demonstrate significant potentials as diagnostic markers for diabetic HCC patients. IGFBP-2 displayed the highest diagnostic accuracy followed by AFP and leptin for HCC and HCCDM groups. This makes it a good marker that can be measured in combination with AFP to increase its sensitivity and specificity in HCC and HCC-DM patients.

\section{DECLARATIONS}

\section{Conflict of Interest}

No conflict of interest associated with this work.

\section{Contribution of Authors}

The authors declare that this work was done by the authors named in this article and all liabilities pertaining to claims relating to the content of this article will be borne by them.

\section{Open Access}

This is an Open Access article that uses a funding model which does not charge readers or their institutions for access and distributed under the terms of the Creative Commons Attribution License (http://creativecommons.org/licenses/by 14.0) and the Budapest Open Access Initiative (http://www.budapestopenaccessinitiative.org/rea d), which permit unrestricted use, distribution, and reproduction in any medium, provided the original work is properly credited.

\section{REFERENCES}

1. Zimmet $P$, Alberti KG, Shaw J. Global and societal implications of the diabetes epidemic. Nature 2001; 414(6865): 782-787.

2. Cohen $D H$, LeRoith $D$. Obesity, type 2 diabetes, and cancer: the insulin and IGF connection. Endocr Relat Cancer 2012; 19(5): F27-45.

3. Donadon V, Balbi M, Zanette G. Hyperinsulinemia and risk for hepatocellular carcinoma in patients with chronic liver diseases and Type 2 diabetes mellitus. Expert Rev Gastroenterol Hepatol 2009; 3(5): 465-467.

4. Lago F, Gomez R, Gomez-Reino JJ, Dieguez C, Gualillo $O$. Adipokines as novel modulators of lipid metabolism. Trends Biochem Sci 2009; 34(10): 500-510.

5. Ahima RS, Flier JS. Leptin. Ann Rev Physiol 2000; 62: 413-437.

6. Gulturk S, Cetin A, Erdal S. Association of leptin with insulin resistance, body composition, and lipid parameters in postmenopausal women and men in type 2 diabetes mellitus. Saudi Med J 2008; 29(6): 813-820.

7. Pollak MN, Schernhammer ES, Hankinson SE. Insulinlike growth factors and neoplasia. Nat Rev Cancer 2004; 4(7): 505-518.

8. Jones Jl, Clemmons DR. Insulin-like growth factors and their binding proteins: biological actions. Endocr Rev 1995; 16(1): 3-34.

9. LeRoith $D$, Roberts $C T$, Jr.. The insulin-like growth factor system and cancer. Cancer Lett 2003; 195(2): 127-137.

10. Rother KI, Accili D. Role of insulin receptors and IGF receptors in growth and development. Pediatr Nephrol 2000; 14(7): 558-561.

11. World Medical A. World Medical Association Declaration of Helsinki: ethical principles for medical research involving human subjects. Jama 2013; 310(20): 2191 2194.

12. Matthews DR, Hosker JP, Rudenski AS, Naylor BA, Treacher DF, Turner RC. Homeostasis model assessment: insulin resistance and beta-cell function from fasting plasma glucose and insulin concentrations in man. Diabetologia 1985; 28(7): 412-419.

13. Turati F, Talamini R, Pelucchi $C$, Polesel J, Franceschi $S$, Crispo A, Izzo F, La Vecchia C, Boffetta P, Montella M. Metabolic syndrome and hepatocellular carcinoma risk. Br J Cancer 2013; 108(1): 222-228.

14. Campbell PT, Newton CC, Patel AV, Jacobs EJ, Gapstur $S M$. Diabetes and cause-specific mortality in a prospective cohort of one million U.S. adults. Diabetes care 2012; 35(9): 1835-1844.

15. Howell J, Yiu M, Gibson R, Thomson B, Stella D, Gorelik A, Prichard PJ, Nicoll AJ. Type 2 diabetes does not worsen prognosis in hepatocellular carcinoma. Clin Res Hepatol Gastroenterol 2011; 35(3): 214-220.

16. Wang WM, Xu Y, Yang XR, Wang $Y H$, Sun $H X$, Fan J. Prognostic role of diabetes mellitus in hepatocellular carcinoma patients after curative treatments: a metaanalysis. Hepatobiliary Pancreat Dis Int 2011; 10(4): 346-355.

17. Belcher G, Schernthaner G. Changes in liver tests during 1-year treatment of patients with Type 2 diabetes with pioglitazone, metformin or gliclazide. Diabet Med 2005; 22(8): 973-979.

18. Catalan V, Gomez-Ambrosi J, Rodriguez A, Salvador J, Fruhbeck G. Adipokines in the treatment of diabetes mellitus and obesity. Expert Opin Pharmacother 2009; 10(2): 239-254.

19. Steinberg GR, Parolin ML, Heigenhauser GJ, Dyck DJ. Leptin increases FA oxidation in lean but not obese human skeletal muscle: evidence of peripheral leptin resistance. Am J Physiol Endocrinol Metab 2002; 283(1): E187-192.

20. Sumner AE, Falkner $B$, Kushner $H$, Considine RV. Relationship of leptin concentration to gender, menopause, age, diabetes, and fat mass in African Americans. Obesity Res 1998; 6(2): 128-133.

21. Wannamethee SG, Lowe GD, Rumley A, Cherry L, Whincup PH, Sattar N. Adipokines and risk of type 2

Trop J Pharm Res, January 2017; 16(1): 217 
diabetes in older men. Diabetes Care 2007; 30(5): 12001205.

22. Sun $Q$, van Dam RM, Meigs JB, Franco $O H$, Mantzoros CS, Hu FB. Leptin and soluble leptin receptor levels in plasma and risk of type 2 diabetes in U.S. women: a prospective study. Diabetes 2010; 59(3): 611-618.

23. Kim C, Park J, Park J, Kang E, Ahn C, Cha B, Lim S, Kim $K$, Lee $H$. Comparison of body fat composition and serum adiponectin levels in diabetic obesity and nondiabetic obesity. Obesity 2006; 14(7): 1164-1171.

24. Murphy LJ. The role of the insulin-like growth factors and their binding proteins in glucose homeostasis. Exp Diabesity Res 2003; 4(4): 213-224.

25. Holt RI, Simpson HL, Sonksen PH. The role of the growth hormone-insulin-like growth factor axis in glucose homeostasis. Diabet Med 2003; 20(1): 3-15.

26. Rajpathak SN, McGinn AP, Strickler $H D$, Rohan $T E$, Pollak M, Cappola AR, Kuller L, Xue X, Newman AB, Strotmeyer ES et al. Insulin-like growth factor-(IGF)-axis, inflammation, and glucose intolerance among older adults. Growth Horm IGF Res 2008; 18(2): 166-173.

27. Heald AH, Cruickshank JK, Riste LK, Cade JE, Anderson $S$, Greenhalgh A, Sampayo J, Taylor W, Fraser W, White $A$ et al. Close relation of fasting insulin-like growth factor binding protein-1 (IGFBP-1) with glucose tolerance and cardiovascular risk in two populations. Diabetologia 2001; 44(3): 333-339.

28. Wheatcroft SB, Kearney MT, Shah AM, Ezzat VA, Miell $J R$, Modo M, Williams SC, Cawthorn WP, MedinaGomez G, Vidal-Puig $A$ et al. IGF-binding protein-2 protects against the development of obesity and insulin resistance. Diabetes 2007; 56(2): 285-294.

29. Russo VC, Schutt BS, Andaloro E, Ymer SI, Hoeflich A, Ranke MB, Bach LA, Werther GA. Insulin-like growth factor binding protein-2 binding to extracellular matrix plays a critical role in neuroblastoma cell proliferation, migration, and invasion. Endocrinology 2005; 146(10): 4445-4455.

30. Kim AY, Lee YS, Kim KH, Lee JH, Lee HK, Jang SH, Kim $S E$, Lee GY, Lee JW, Jung $S A$ et al. Adiponectin represses colon cancer cell proliferation via AdipoR1and -R2-mediated AMPK activation. Mol Endocrinol 2010; 24(7): 1441-1452.

31. Han G, Wang L, Zhao R, Yue Z, Zhou X, Hu X, Cao Y, Dai D, Liu J. Leptin promotes human glioblastoma growth through activating Signal Transducers and Activators of Transcription 3 signaling. Brain Res Bull 2012; 87(2-3): 274-279.

32. Liu Y, Lv L, Xiao W, Gong $C$, Yin J, Wang D, Sheng $H$. Leptin activates STAT3 and ERK1/2 pathways and induces endometrial cancer cell proliferation. $J$ Huazhong Univ Sci Technolog Med Sci 2011; 31(3): 365-370.

33. Saxena NK, Sharma D, Ding X, Lin S, Marra F, Merlin D, Anania FA. Concomitant activation of the JAK/STAT, $P I 3 K / A K T$, and ERK signaling is involved in leptinmediated promotion of invasion and migration of hepatocellular carcinoma cells. Cancer Res 2007; 67(6): 2497-2507.

34. Sadik NA, Ahmed A, Ahmed S. The significance of serum levels of adiponectin, leptin, and hyaluronic acid in hepatocellular carcinoma of cirrhotic and noncirrhotic patients. Hum Exp Toxicol 2012; 31(4):311-321.

35. Firth SM, Baxter RC. Cellular actions of the insulin-like growth factor binding proteins. Endocr Rev 2002; 23(6): 824-854.

36. Ranke MB, Maier KP, Schweizer R, Stadler B, Schleicher $S$, Elmlinger MW, Flehmig B. Pilot study of elevated levels of insulin-like growth factor-binding protein-2 as indicators of hepatocellular carcinoma. Horm Res 2003; 60(4): 174-180.

37. Rehem RN, El-Shikh WM. Serum IGF-1, IGF-2 and IGFBP-3 as parameters in the assessment of liver dysfunction in patients with hepatic cirrhosis and in the diagnosis of hepatocellular carcinoma. Hepatogastroenterology 2011; 58(107-108): 949-954.

38. Hoeflich A, Reisinger R, Lahm H, Kiess W, Blum WF, Kolb HJ, Weber MM, Wolf E. Insulin-like growth factorbinding protein 2 in tumorigenesis: protector or promoter? Cancer Res 2001; 61(24): 8601-8610. 